\section{Suaeda salsa, A Desalinating Companion Plant for Greenhouse Tomato}

\author{
Mohammed S. Albaho ${ }^{1}$ and James L. Green ${ }^{2}$ \\ Department of Horticulture, Oregon State University, Corvallis, \\ OR 97331-7304
}

Additional index words. salinity, desalination, halophyte, closed insulated pallet system, blossom end rot, Lycopersicon esculentum, seepweed

\begin{abstract}
To determine its effect on salinity of the growth medium and on tomato (Lycopersicon esculentum Mill.) growth and yield, the halophyte Suaeda salsa (L.) Pallas, or seepweed, was planted as a companion plant in the closed insulated pallet system (CIPS). In this production system, water moves from a bottom reservoir through capillary wicks to the medium in the root pouch in response to plant uptake. Fertilizers are placed at the top surface of the root matrix, so nutrient ions move downward to the roots by chemical ion diffusion to establish relatively stable chemical gradients within the matrix. Plants were subjected to capillary subirrigation water containing 0 or $4 \mathbf{g} \cdot \mathbf{L}^{-1} \mathbf{N a C l}$. Sodium $\left(\mathrm{Na}^{+}\right)$ concentration of the root medium at termination was $50 \%$ lower when $S$. salsa was grown in the same pouch with tomato. Sodium concentration was also significantly less in the tomato foliage, but $S$. salsa did not prevent suppression of growth of tomato plants by $\mathrm{NaCl}$. Suaeda salsa plants reduced blossom end rot of tomato fruit but did not significantly affect fruit weight, number or yield.
\end{abstract}

In the closed insulated pallet system(CIPS), salinity in the root medium may increase during tomato production, especially when the irrigation water is high in $\mathrm{NaCl}$. High salinity in the plant rootzone either retards the plant's ability to take up water from the soil solution or is toxic, thereby limiting growth and fruit yield. Tomato has been classified as a moderately salt-tolerant crop (Bernstein, 1964). Tomato yield was reduced by $50 \%$ when the electrical conductivity (EC) of the soil solution was increased to $7.6 \mathrm{dS} \cdot \mathrm{m}^{-1}$ or $\approx 4.86 \mathrm{~g} \cdot \mathrm{L}^{-1}$ (Sanchez and Silvertooth, 1996). However, solute ions may accumulate in the growth medium of CIPS and can lead to an EC much higher than 7.6 $\mathrm{dS} \cdot \mathrm{m}^{-1}$. Jones (1986) reported that tomato selectively excluded sodium $\left(\mathrm{Na}^{+}\right)$ions from its roots. Halophytic plant species that desalinize saline soils have been used to increase crop yields on soils with marginal salinity. Major plant species used to improve arid pastures around the world include Atriplex sp., Distichilis sp., Jouvea sp., Allenroflea sp., Salicornia

Received for publication on 24 Mar. 1999. Accepted for publication 30 Aug. 1999. Part of a dissertation submitted by Mohammed Albaho in partial fulfillment of the requirements for the $\mathrm{PhD}$ degree. Mention of a trade names does not constitute a guarantee or warranty of the products by Oregon State Univ. and does not imply its approval to the exclusion of other products or vendors that also may be suitable. The cost of publishing this paper was defrayed in part by the payment of page charges. Under postal regulations, this paper therefore must be hereby marked advertisement solely to indicate this fact.

${ }^{1}$ Current address: Kuwait Inst. for Scientific Research/ A.A.D., P.O. Box 24885, Safat 13109, Kuwait. E-mail address: mbahouh@kisr.edu.kw ${ }^{2}$ Professor of Horticulture. europaea L., and Suaeda fruticosa Forssk. ex Gmelin (Kovalev and Krylova, 1992). Important properties of halophytes are the use of $\mathrm{NaCl}$ as an osmoticum and the compartmentalization of $\mathrm{Na}^{+}$and $\mathrm{Cl}^{-}$in leaf vacuoles. This is achieved through extremely low permeability of the tonoplast to these toxic ions (Maathuis et al., 1992). Suaeda salsa is a halophyte that removes $\mathrm{Na}^{+}$ and $\mathrm{Cl}^{-}$from the root medium and compartmentalizes these ions in the leaf vacuoles (Maathuis et al., 1992). Suaeda salsa decreased $\mathrm{Na}^{+}$in field soils by $4.5 \%$ with plant density of 15 plants $/ \mathrm{m}^{2}$ and by $6.7 \%$ at 30 plants $/ \mathrm{m}^{2}$ (Zhao, 1991). In container experiments, $S$. salsa reduced $\mathrm{Na}^{+}$content from 20.6 to 10.0 g per $9-\mathrm{L}$ pot (Zhao, 1991). In the current study, we hypothesized that the $S$. salsa might remove sufficient ions from the medium to affect tomato performance when grown in CIPS. This is important, particularly in areas where poor quality water is the only source for irrigation. Suaeda salsa foliage can be used in animal feed as a byproduct when grown with high cash crops to enhance growers' incomes. The objective of our study was to evaluate the effect of $S$. salsa on salinity of the growth medium, and on tomato growth and yield when planted as a companion plant in the same CIPS pouch with tomato.

\section{Materials and Methods}

Production system. The CIPS (Fig. 1) has been described by Albaho (1998), Blackburn (1992), Briggs and Green (1991), Green et al. (1993a, 1993b), Green and Schneckenburger (1992), and Kelly et al. (1997). It is a continuous subirrigation-capillary system in which water movement is plant-driven in response to uptake to support transpiration and growth. In CIPS, fertilizers are placed at the top of the growth medium. Nutrient ions move downward slowly by chemical diffusion to establish relatively stable chemical gradients.

The bottom, top, and sidewalls enclosing the root environment were impermeable to water. They were opaque, reflective, and insulated to prevent transfer of light, heat, and moisture. Each pallet base reservoir had a volume of $262 \mathrm{~L}$. Pallet tops were covered with reflective, heavy-duty aluminum foil. A collar was fitted around the plant stem, extending and sealing to the surrounding lid. Waterimpermeable, nonphytotoxic, triple-expanding polyurethane foam completed the seal between the plant stem and collar without restricting growth. Water- and air-permeable root pouches were constructed of spunbonded polypropylene [e.g., Agro fabric PRO70, 47.4 $\mathrm{g} \cdot \mathrm{m}^{-2}$ (American Agrifabrics PCK, Alpharetta, Ga.) or Kimberly Clark $11564-00,63.8 \mathrm{~g} \cdot \mathrm{m}^{-2}$ SMS filter fabric (Kimberly-Clark, Rosewell, $\mathrm{Ga}$.)] and sewn with polyester thread. To regulate root growth and confine the roots within the pouch, the pouches were treated with a copper-latex solution $\left\{100 \mathrm{~g} \cdot \mathrm{L}^{-1}\right.$ Kocide (Griffen Corp., Valdosta, Ga.) 101 WP [77\% $\mathrm{Cu}(\mathrm{OH})_{2}, 60 \mu \mathrm{g} \cdot \mathrm{L}^{-1}$ soluble copper] in latex paint diluted $1: 1(\mathrm{v} / \mathrm{v})$ with water .

Baskets were constructed from $15-\mathrm{cm}$ diameter $\times 17$-cm-deep polyethylene nursery containers, with rectangular openings cut from four sides. The pouches were suspended from the CIPS lid within the containers placed in the precut holes; the suspended container was supported by the container-lip/lid overlap. Capillary strips (spunbonded polyester fabric 10.2 - $\mathrm{cm}$ wide $\times 46-\mathrm{cm}$ long; Troy Mills, Troy, N.H.) were placed across the bottom of the basket. The bottom of the pouch was in direct contact with the capillary mat and the ends of the capillary strip extended downward $15 \mathrm{~cm}$ to the bottom of the water reservoir in the base of the CIPS pallet. Water moved by capillary and adsorptive forces. The Troy capillary material has a vertical water capillary rise of $\approx 13$ to 15 $\mathrm{cm}$. Water moved upward against gravity in response to surface adsorption, capillary, diffusive, and hygroscopic forces ranging from $>1$ to $\approx 300,000$ times the force of gravity.

The rooting medium used was 1 peatmoss (Canadian sphagnum) : 1 horticultural grade vermiculite $(\mathrm{v} / \mathrm{v})$ that was sufficiently fine to provide capillary movement of water. In the medium, $3.0 \mathrm{~kg} \cdot \mathrm{m}^{-3}$ dolomite $\left(\mathrm{CaCO}_{3}\right.$ and $\left.\mathrm{MgCO}_{3}\right)$ and $1.8 \mathrm{~kg} \cdot \mathrm{m}^{-3}$ gypsum $\left(\mathrm{CaSO}_{4} \cdot \mathrm{H}_{2} \mathrm{O}\right)$ were uniformly incorporated to provide $\mathrm{Ca}^{2+}$, $\mathrm{Mg}^{2+}$, and $\mathrm{S}$, and to adjust $\mathrm{pH}$. The volume of each pouch was $2 \mathrm{~L}$; planting density was 7.5 plants $/ \mathrm{m}^{2}$.

After planting, the medium was initially moistened to field capacity to establish capillarity. Prior to addition of fertilizer, the base level total dissolved solutes (TDS) of the growth medium was $1 \mathrm{~g} \cdot \mathrm{L}^{-1}$. After draining gravitational water, fertilizer was applied to the perimeter of the top surface away from the young plant roots. Plants were fertilized with $20 \mathrm{~g}$ controlled-release $17 \mathrm{~N}-2.6 \mathrm{P}-10 \mathrm{~K}$ plus micronutrients (Scotts-Sierra Horticultural Products Co., Marysville, Ohio) and $20 \mathrm{~g}$ soluble $\mathrm{Ca}\left(\mathrm{NO}_{3}\right)_{2} \cdot 4 \mathrm{H}_{2} \mathrm{O}$. Fertilizers were 


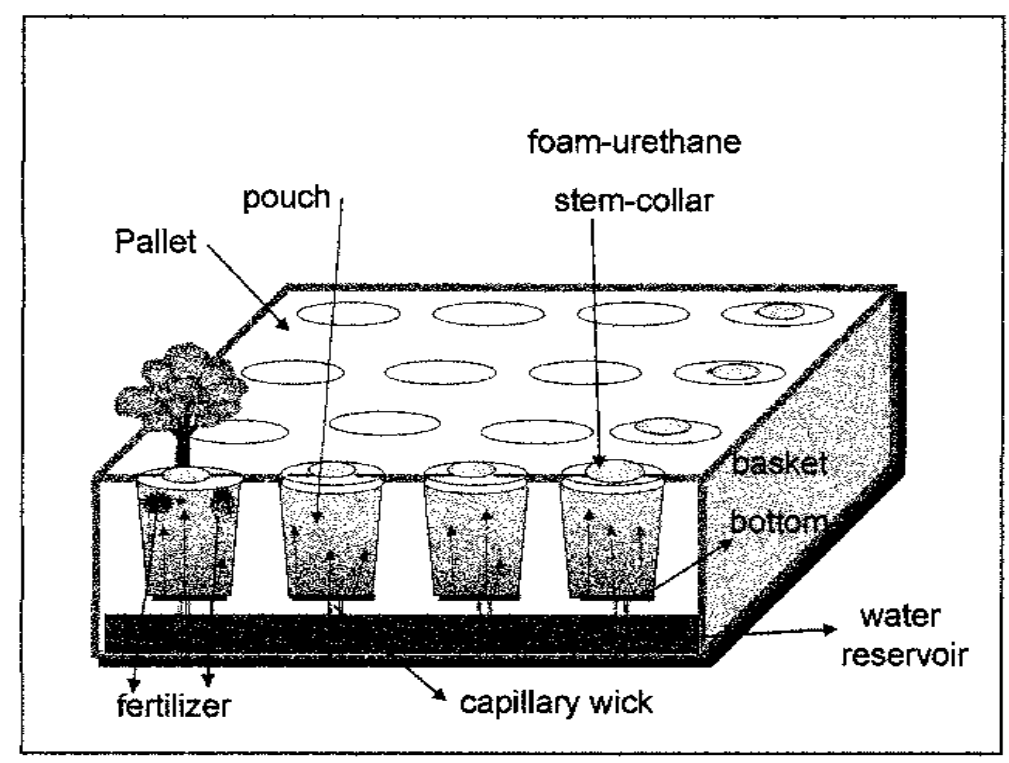

Fig. 1. The closed insulated pallet system (CIPS) unit. Each pallet can hold 16 plants (pouches) with a reservoir capacity of $262 \mathrm{~L}$ of water. In each pouch, either one or two plants are placed. (Modified from Green et al., 1999).

placed on the surface at the perimeter of the pouched growth medium. The plant collar was then installed, and the stem sealant applied so that the fertilizer was shielded from surfaceapplied water and from gravitational and evaporative water-flow pathways. Solubilized fertilizer ions moved by diffusion in accordance with Fick's laws from the top-placed fertilizer reserve and established ion concentration gradients to the plant roots and other areas of lower solute concentration (Blackburn, 1992; Kelly et al., 1997).

Plant materials. Seeds of S. salsa were obtained from Dr. Kefu Zhao, Dept. of Biology, Shandong Teachers Univ., Jinan, China. Because of slower growth, seeds were sown $30 \mathrm{~d}$ before the tomato seeds. Suaeda seeds for the spring trial were sown in $5-\mathrm{cm}$ plastic cubes containing 1 peat : 1 vermiculite $(v / v)$ on 24 Jan. 1996 and transplanted into CIPS pouches on 24 Feb. 1996. Seeds for the autumn trial were sown on 20 July 1996 and transplanted on 20 Aug. 1996. Nutrients were supplied in a Long Ashton mineral solution (Hewitt, 1966) from seedling emergence until the date of transplanting.

Three seeds each of an early hybrid tomato (cv. Pik Red) were sown directly into CIPS pouches on 24 Feb. 1996 (spring trial), and on 20 Aug. 1996 (autumn trial). Seedlings were selected for uniformity of size and thinned to one per pouch immediately after second true-leaf expansion. There were three combinations of plants per pouch: tomato alone, Suaeda alone, and both species together. Flowers were pollinated with a battery-powered tomato pollinator for a few seconds each plant around midday, three or four times per week.

Plants were grown in a glass greenhouse with perimeter and under-bench hot-water pipe heating with a minimum temperature setting of $18{ }^{\circ} \mathrm{C}$. Cooling by roof vents, fans, and evaporative-cooling pads was activated at $24{ }^{\circ} \mathrm{C}$. Plants were exposed to ambient $\mathrm{CO}_{2}$ and humidity. Plants received $16 \mathrm{~h}(0700$ to 2300) daily supplementary irradiation with 400-watt high-pressure sodium lamps centered $182 \mathrm{~cm}$ above each CIPS unit $(200$ $\left.\mu \mathrm{mol} \cdot \mathrm{m}^{-2} \cdot \mathrm{s}^{-1}\right)$. In the autumn trial, light supplementation began on 13 Sept. 1996. The spring 1996 and 2 Dec. 1996, respectively. Average solar irradiance was 352.9 langleys (14995.8 $\mathrm{KJ} \cdot \mathrm{m}^{-2}$ ) per day for the spring trial and 228.7 langleys $\left(9567.8 \mathrm{KJ} \cdot \mathrm{m}^{-2}\right)$ per day for the autumn trial.

Data measurements. Sodium $\left(\mathrm{Na}^{+}\right)$and $\mathrm{Cl}^{-}$concentrations in plant foliage and root media were determined at termination of each trial. Sodium was analyzed by ICP Spectrometer (Perkin-Elmer Optima 3000 DV; PerkinElmer Corp., Norwalk, Conn.) and $\mathrm{Cl}^{-}$was analyzed by Dionex Ion Chromatography (Dionex 2000I; Dionex Corp., Sunnyvale, Calif.). EC of the root media was also determined using the saturated paste method. Fresh weight of shoots (leaves, petioles, and stems) of tomato and S. salsa and fruit yield per tomato plant were recorded. Dry weight of shoots (leaves, petioles, and stems) was determined after oven-drying at $60{ }^{\circ} \mathrm{C}$ for $48 \mathrm{~h}$. Concentrations of $\mathrm{P}, \mathrm{K}^{+}, \mathrm{Ca}^{2+}, \mathrm{Mg}^{2+}$, and $\mathrm{Mn}^{2+}$ were determined in both the plant foliage (ICP Spectrometer) and growth medium, after extraction with ammonium acetate (Horneck et al. 1989), and analyzed by atomic absorption (Perkin-Elmer Atomic Absorption Spectrometer 372; Perkin-Elmer Corp.). Measurements of the $\mathrm{Cu}^{2+}$ concentration in the growth media in CIPS revealed that it was not influenced by the pouch treatment with cupric hydroxide and sured in this experiment.

Experimental design. The experiment was a two-factor, split-plot design, with three plant and autumn trials were terminated on 22 June therefore $\mathrm{Cu}^{2+}$ concentrations were not mea- combinations (tomato alone, tomato with $S$. salsa in the same root pouch, and $S$. salsa alone) and two subirrigation water salinities ( 0 and 4 $\mathrm{g} \cdot \mathrm{L}^{-1} \mathrm{NaCl}$ ). Four replicates per plant combination were randomized within each salinity treatment. Salinity was the main plot factor and plant combination was the subplot factor.

Statistical analyses. Analysis of variance (ANOVA) was performed by SAS Institute procedures (SAS Inst., 1996). Fisher's protected least significant difference (LSD) test was used to separate means. Shoot weight and elemental concentrations in the foliage were analyzed for each species separately.

In pouches where both species were placed together, tomato will be referred to as (T+), $S$. salsa as (S+), and their growth medium as $(\mathrm{T}+\mathrm{S})$. Tomato-alone $(\mathrm{T})$ was the control for tomato plants grown with Suaeda $(\mathrm{T}+)$. Suaeda alone (S) was the control for Suaeda plants grown with tomato $(\mathrm{S}+)$. Analyses of $\mathrm{Na}^{+}$or $\mathrm{Cl}^{-}$were performed on the $4 \mathrm{~g} \cdot \mathrm{L}^{-1}$ water treatment only.

\section{Results}

Effect of S. salsa on salinity of growth medium. S. salsa reduced the $\mathrm{Na}^{+}$concentration $50.8 \%$ and the EC of the growth medium $45.2 \%$, when capillary-irrigated with $4 \mathrm{~g} \cdot \mathrm{L}^{-1}$ $\mathrm{NaCl}$ water in the spring trial (Table 1). Reduction in $\mathrm{Cl}^{-}$concentration in the medium was not significant in either trial. With $S$. salsa, the growth medium was slightly acidified (pH 5.16 and 5.08 with $S$. salsa compared with $\mathrm{pH} 5.40$ and 5.46 without $S$. salsa in 0 and $4 \mathrm{~g} \cdot \mathrm{L}^{-1} \mathrm{NaCl}$ water treatment, respectively); the $\mathrm{pH}$ was lower with $S$. salsa regardless of salinity treatment or plant combination. Results were similar in the autumn trial.

With high-salinity subirrigation water, the concentration of $\mathrm{Mg}^{2+}$ was significantly lower in the root medium with $\mathrm{S}$ than with $\mathrm{T}$ (Fig. 2). No other elements were significantly influenced by salinity. The $\mathrm{Mg}^{2+}: \mathrm{Ca}^{2+}$ in the solution were $0.26,0.19$, and $0.12\left(\mathrm{LSD}_{0.05}=0.06\right)$ for $\mathrm{T}, \mathrm{T}+\mathrm{S}$, and $\mathrm{S}$, respectively, and 0.25 and $0.13\left(\mathrm{LSD}_{0.05}=0.09\right)$ in the control and saline treatment, respectively.

Effect of S. salsa on ion concentration in tomato foliage. Adding $4 \mathrm{~g} \cdot \mathrm{L}^{-1} \mathrm{NaCl}$ to the subirrigation water reduced $\mathrm{Na}^{+}$concentration in tomato foliagein the presence of S. salsa $(\mathrm{T}+)$ $37.6 \%$ in the spring trial (Table 1), but had no significant affect in the autumn trial (data not shown). Concentration of $\mathrm{P}$ in tomato foliage was significantly higher with $0 \mathrm{~g} \cdot \mathrm{L}^{-1}$ than with $4 \mathrm{~g} \cdot \mathrm{L}^{-1} \mathrm{NaCl}$ irrigation water whether accompanied by $S$. salsa or not (Table 2). However, concentration of $\mathrm{Mn}^{2+}$ was much higher in the foliage of tomato plants irrigated with saline water. Magnesium was greater in tomato foliage grown alone (T) than when grown with $S$. salsa $(\mathrm{T}+\mathrm{S})$. Concentrations of $\mathrm{NO}_{3}^{-}, \mathrm{K}^{+}$, and $\mathrm{Ca}^{2+}$ in the foliage were not influenced by salinity level whether grown alone or with $S$. salsa.

Effect of S. salsa on tomato growth and yield. The dry weights of tomato plants and fruits were significantly less with $4 \mathrm{~g} \cdot \mathrm{L}^{-1}$ than with $0 \mathrm{~g} \cdot \mathrm{L}^{-1} \mathrm{NaCl}$ irrigation water in the 
Table 1. Influence of Suaeda salsa on sodium $\left(\mathrm{Na}^{+}\right)$concentration in 'Pik Red' tomato foliage and on sodium concentration and electrical conductivity (EC) of the growth medium measured at termination of experiment subirrigated with $4 \mathrm{~g} \cdot \mathrm{L}^{-1} \mathrm{NaCl}$ (spring).

\begin{tabular}{lccc}
\hline \hline Plant combination & $\begin{array}{c}\mathrm{Na}^{+} \text {concentration in } \\
\text { growth medium }(\mathrm{meq} / 100 \mathrm{~g})\end{array}$ & $\begin{array}{c}\text { EC of growth } \\
\text { medium }\left(\mathrm{dS} \cdot \mathrm{m}^{-1}\right)\end{array}$ & $\begin{array}{c}\text { Na concentration in } \\
\text { tomato foliage }\left(\mathrm{g} \cdot \mathrm{kg}^{-1} \mathrm{dwt}\right)\end{array}$ \\
\hline Tomato alone & 186.8 & 43.4 & 4.65 \\
Tomato + S. salsa & 91.8 & 29.9 & 2.90 \\
Significance & $* *$ & $* *$ & $* *$
\end{tabular}

${ }^{* *}$ Significant at $P \leq 0.01$.

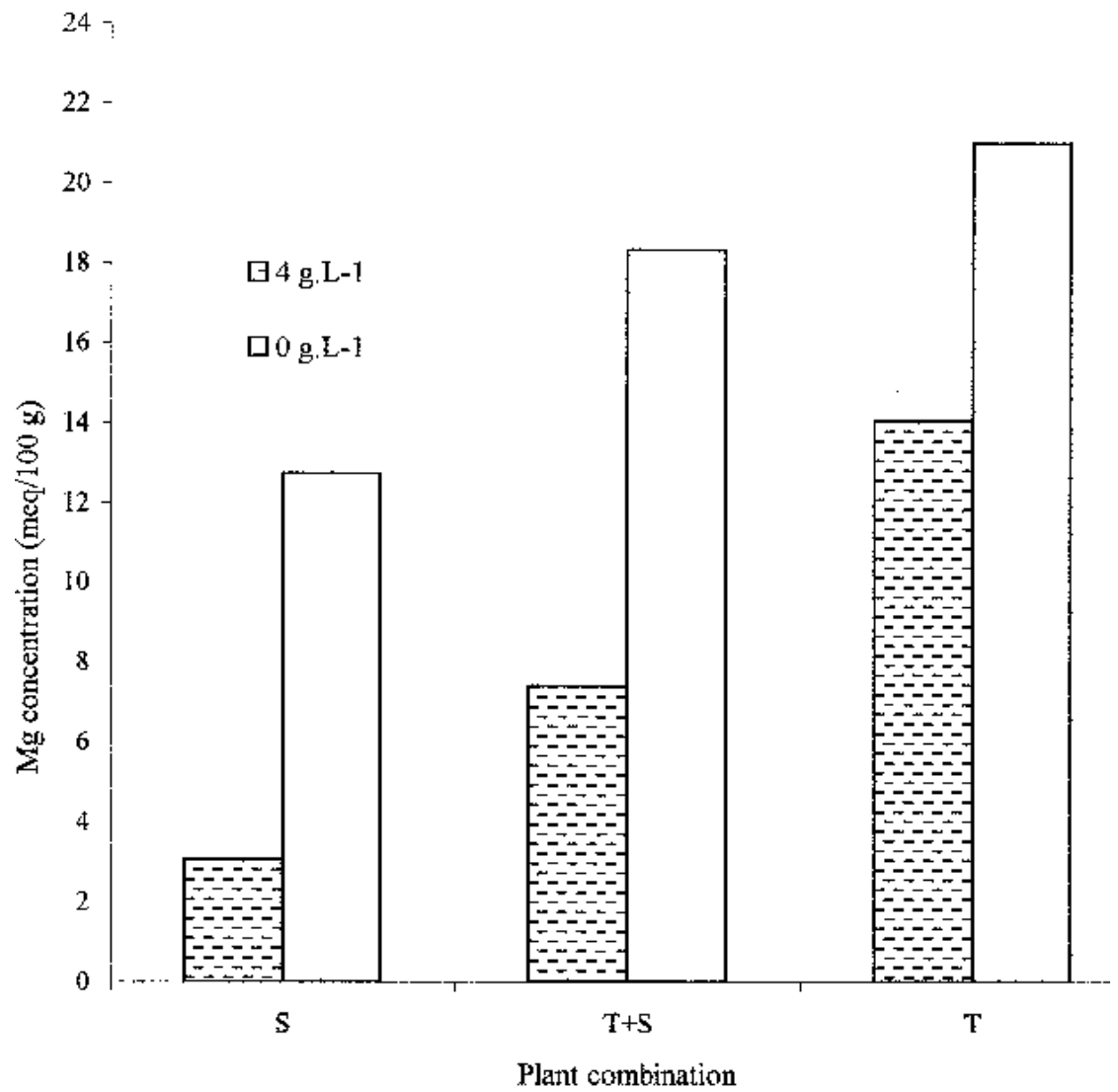

Fig. 2. Magnesium $\left(\mathrm{Mg}^{+2}\right)$ concentration of growth medium for plant combinations [tomato (T), Suaeda (S), or $\mathrm{T}+\mathrm{S}$ irrigated at two salinity levels $(\mathrm{SE}=2.67$; spring $)]$.

Table 2. Main effects of salinity and of Suaeda salsa as a companion plant on ion concentration in 'Pik Red' tomato foliage (autumn).

\begin{tabular}{|c|c|c|c|c|}
\hline \multicolumn{2}{|c|}{ Treatment } & $\mathrm{P}(\%)$ & $\mathrm{Mn}^{2+}\left(\mathrm{mg} \cdot \mathrm{L}^{-1}\right)$ & $\overline{\mathrm{Mg}^{2+}(\%)}$ \\
\hline \multirow[t]{2}{*}{ Water salinity $\left(\mathrm{g} \cdot \mathrm{L}^{-1} \mathrm{NaCl}\right)$} & 0 & 0.78 & 164.9 & 0.70 \\
\hline & 4 & 0.56 & 251.9 & 0.80 \\
\hline \multirow{4}{*}{ Plant combination } & Significance & * & * & NS \\
\hline & $\mathrm{T}^{\mathrm{z}}$ & 0.73 & 231.9 & 0.84 \\
\hline & $\mathrm{T}+$ & 0.61 & 184.9 & 0.66 \\
\hline & Significance & NS & NS & $*$ \\
\hline
\end{tabular}

${ }^{2}$ Tomato alone (T), or with $S$. salsa in same pouch (T+).

Ns, * Nonsignificant or significant at $P \leq 0.05$.

spring trial (Table 3). The $S$. salsa companion plant had no significant effect on tomato growth (e.g., dry weight of shoot), fruit weight per plant or weight per fruit. However, presence of $S$. salsa reduced blossom-end rot (BER) from $17.5 \%$ to $9.2 \%$. Furthermore, addition of $\mathrm{NaCl}$ to the subirrigation water reduced BER in spring (Table 3 ). In the autumn trial, BER was not affected but was generally much lower than in spring (Table 3 ), probably because of the lower growth rate in autumn. BER is a widespread physiological disorder caused by local $\mathrm{Ca}^{2+}$ deficiency and loss of selective permeability of the cell membranes in developing fruit (Simon, 1978; Van Goor, 1968).

In the autumn trial, similar results were obtained for growth and fruit weight parameters. However, incidence of BER was generally extremely low and was not significantly affected by the presence of $S$. salsa or by $\mathrm{NaCl}$ concentration (Table 3 ).
Growth of S. salsa. Suaeda salsa alone (S) grew more in the saline than in nonsaline water (Table 4), an indication that $S$. salsa has an obligate requirement for $\mathrm{Na}^{+}$for optimal growth and development. When $S$. salsa was grown with tomato in the same root pouch $(\mathrm{S}+)$, its dry shoot weight was reduced by $38.7 \%$.

Concentrations of $\mathrm{Na}^{+}$and $\mathrm{Cl}^{-}$in $S$. salsa foliage were not affected by the presence of tomato plants (data not shown). Phosphorus (P) and $\mathrm{Ca}^{2+}$ concentration in the foliage were much greater in $0 \mathrm{~g} \cdot \mathrm{L}^{-1}$ than in the $4-\mathrm{g} \cdot \mathrm{L}^{-1} \mathrm{NaCl}$ water treatment (Table 4). However, concentrations of these elements were similar in $\mathrm{S}$ and $\mathrm{S}+$. Suaeda salsa alone (S) at either salinity level had greater foliar concentrations of $\mathrm{Mn}^{2+}$ $(P \leq 0.05)$ and $\mathrm{NO}_{3}^{-}(P \leq 0.01)$ than did $\mathrm{S}+$. Potassium $\left(\mathrm{K}^{+}\right)$and $\mathrm{Mg}^{2+}$ concentrations in $\mathrm{S}$ and $\mathrm{S}+$ were similar regardless of water salinity for $\mathrm{S}$ or $\mathrm{S}+$.

\section{Discussion}

Although $S$. salsa considerably reduced EC and $\mathrm{Na}^{+}$concentration of the medium (Table 1 ), the reduction may have been insufficient to improve tomato plant growth and fruit yield (Tables 3 and 4) because of the high $\mathrm{NaCl}$ concentration in the capillary irrigation water (4 g. $\left.\mathrm{L}^{-1}\right)$. The poorer growth of $S$. salsa in $0 \mathrm{~g} \cdot \mathrm{L}^{-1} \mathrm{NaCl}$ than in $4 \mathrm{~g} \cdot \mathrm{L}^{-1} \mathrm{NaCl}$ was attributed to its obligate sodium requirement.

The $\mathrm{Mg}^{2+}$ to $\mathrm{Ca}^{2+}$ ratio of the medium was greater in the control than in the saline treatment and percentage BER was lower in the saline treatment than in the control (Table 3) Furthermore, the lower $\mathrm{Mg}^{2+}$ concentration in both growth media (Fig. 2) and in tomato foliage (T+, Table 2) in the presence of $S$. salsa than in its absence may indicate that $S$. salsa has a high demand for $\mathrm{Mg}^{2+}$ as well. Moreover, the significantly lower $\mathrm{Mg}^{2+}$ to $\mathrm{Ca}^{2+}$ ratio in the medium when $S$. salsa was present may have reduced BER in tomato fruit. This is supported by the substantially lower $\mathrm{Mg}^{2+}$ to $\mathrm{Ca}^{2+}$ ratio in the saline than in the control medium where BER was much more severe. Incidence of BER may be more related to ion balance (ionic ratio) than to intensity. For instance, high $\mathrm{K}^{+}$or $\mathrm{Mg}^{2+}$ in relation to the $\mathrm{Ca}^{2+}$ in solution may increase BER (Adams, 1991; Ehret and Ho, 1986; Willumsen et al., 1996). Any factor that reduces incidence of BER is noteworthy, as this physiological disorder causes serious economic losses annually.

In the autumn trial, the very low \% BER (Table 3) was probably a result of the low solar irradiance in this season, as increasing irradiance would increase photosynthesis and thus increase import of carbohydrates for fruit growth (Ho et al., 1993). Higher irradiance also tends to increase ambient temperature, which in turn stimulates fruit enlargement.

Data for foliage $\mathrm{NO}_{3}{ }^{-}$concentrations (Table 4) indicate that the tomato plant was more competitive for $\mathrm{NO}_{3}{ }^{-}$than was $S$. salsa, especially in nonsaline water. As for the remaining elements $\left(\mathrm{K}^{+}, \mathrm{Ca}^{2+}, \mathrm{Mn}^{2+}\right.$, and $\left.\mathrm{P}\right)$, their concentrations were not affected. Nutri- 
Table 3. Main effects of salinity and of Suaeda salsa as a companion plant on dry shoot weight, fruit weight per plant, fresh weight per fruit, and incidence of blossom-end rot (BER) in 'Pik Red' tomato.

\begin{tabular}{|c|c|c|c|c|c|}
\hline \multicolumn{2}{|c|}{ Treatment $^{\mathrm{z}}$} & $\begin{array}{c}\text { Dry shoot } \\
\text { mass }(g)\end{array}$ & $\begin{array}{l}\text { Fruit wt/ } \\
\text { plant (g) }\end{array}$ & $\begin{array}{c}\text { Fresh wt/ } \\
\text { fruit }(\mathrm{g})\end{array}$ & $\begin{array}{c}\text { BER } \\
(\% \text { of fruits) }\end{array}$ \\
\hline \multicolumn{6}{|c|}{ Expt. 1. Spring } \\
\hline \multirow[t]{3}{*}{ Water salinity $\left(\mathrm{g} \cdot \mathrm{L}^{-1} \mathrm{NaCl}\right)$} & 0 & 61.9 & 1008.4 & 91.9 & 19.0 \\
\hline & 4 & 33.9 & 416.6 & 61.8 & 7.7 \\
\hline & Significance & $* *$ & $*$ & $*$ & $*$ \\
\hline \multirow[t]{3}{*}{ Plant combination } & $\mathrm{T}^{\mathrm{z}}$ & 52.4 & 675.8 & 74.1 & 17.5 \\
\hline & $\mathrm{T}+$ & 43.4 & 749.2 & 79.6 & 9.2 \\
\hline & Significance & NS & NS & NS & $*$ \\
\hline \multicolumn{6}{|c|}{ Expt. 2. Autumn } \\
\hline \multirow[t]{3}{*}{ Water salinity $\left(\mathrm{g} \cdot \mathrm{L}^{-1} \mathrm{NaCl}\right)$} & 0 & 47.6 & 981.2 & 136.0 & 3.2 \\
\hline & 4 & 28.5 & 589.2 & 111.9 & 1.3 \\
\hline & Significance & $*$ & $*$ & $*$ & NS \\
\hline \multirow[t]{3}{*}{ Plant combination } & $\mathrm{T}$ & 42.5 & 789.2 & 132.6 & 3.2 \\
\hline & $\mathrm{T}+$ & 33.6 & 761.2 & 115.3 & 1.3 \\
\hline & Significance & NS & NS & NS & NS \\
\hline
\end{tabular}

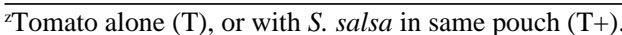

Ns, *, ** Nonsignificant or significant at $P \leq 0.05$ or 0.01 .

Table 4. Main effects of salinity and of tomato as a companion plant on shoot dry weight and of ion concentration at harvest in Suaeda salsa foliage when grown alone (S) or with the tomato cv. Pik Red (S+) in a single root pouch (autumn).

\begin{tabular}{|c|c|c|c|c|c|c|}
\hline \multicolumn{2}{|c|}{ Treatment } & Dry shoot wt $(\mathrm{g})$ & $\mathrm{P}(\%)$ & $\mathrm{Ca}^{2+}(\%)$ & $\mathrm{NO}_{3}^{-}(\%)$ & $\mathrm{Mn}^{2+}\left(\mathrm{mg} \cdot \mathrm{L}^{-1}\right)$ \\
\hline \multirow[t]{3}{*}{ Water salinity } & 0 & 12.8 & 1.32 & 2.33 & 1.06 & 105.2 \\
\hline & 4 & 27.8 & 0.68 & 1.57 & 0.98 & 116.0 \\
\hline & Significance & $* *$ & $* * *$ & $*$ & NS & NS \\
\hline \multirow[t]{3}{*}{ Plant combination } & S & 24.3 & 1.02 & 2.23 & 1.43 & 131.0 \\
\hline & $\mathrm{S}+$ & 16.3 & 1.98 & 1.67 & 0.61 & 90.2 \\
\hline & Significance & $*$ & NS & NS & $* *$ & $*$ \\
\hline
\end{tabular}

ss, ***, ,***Nonsignificant or significant at $P \leq 0.05,0.01$, or 0.001 .

ent concentrations in tomato foliage were within the range for a healthy tomato crop (Winsor et al., 1980).

Competition for light between tomato and $S$. salsa companion plantings may have reduced growth of $S$. salsa; its shoot dry weight was significantly reduced when it shared a root pouch with tomato (Table 4). Light was probably not limiting for the taller tomato plant; its growth was unaffected by the presence of S. salsa (Table 3).

A wide range of irrigation water salinity concentrations, including those lower than $4 \mathrm{~g} \cdot \mathrm{L}^{-1}$ $\mathrm{NaCl}$, needs to be evaluated. A NaCl concentration of only $0.2 \mathrm{~g} \cdot \mathrm{L}^{-1}$ was used by Zhao (1991) for testing Suaeda as a desalinator for Medicago sativa L. This was considerably less than the $4 \mathrm{~g} \cdot \mathrm{L}^{-1}$ employed in our investigation. Salinity alleviation is an important issue, as salt accumulation is a major concern in CIPS when available irrigation water is of poor quality.

Tomato cultivars that are more salt-tolerant should be evaluated with the companion S. salsa. Also, other salt-loving plant species, such as Atriplex and Salicornia, and other Suaeda sp. should be tested as salt absorbers when planted
Acta Hort. 511:59-64.

Green, J.L., B. Briggs, and D. Briggs. 1993a. Fertilizing apparatus. U.S. Patent No. 5,212,904 assigned to the State of Oregon, acting by and through the State Board of Higher Educ. on behalf of Oregon State Univ. Issued by the U.S. Patent Office, 25 May 1993.

Green, J.L., S. F. Kelly, B. Blackburn, J. Robbins, B.A. Briggs, and D.L. Briggs. 1993b. A protected diffusion zone (PDZ) to conserve soluble production chemicals. Combined Proc. Intl. Plant Prop. Soc. 43:40-44.

Green, J.L. and R. Schneckenburger. 1992. Pallet system for container-grown plants. U.S. Patent $5,170,581$. Assigned to the State of Oregon, acting by and through the State Board of Higher Educ. on behalf of Oregon State Univ. 2 June 1992.

Hewitt, E.J. 1966. Sand and water culture methods used in the study of plant nutrition. Tech. Comm. No. 22 ( $2^{\text {nd }}$ ed., revised), Cmnwlth. Agr. Bur., Maidstone, Kent, England.

Ho, L.C., R. Belda, M. Brown, J. Andrews, and P. Adams. 1993. Uptake and transport of $\mathrm{Ca}$ and the possible causes of blossom-end rot in tomato. J. Expt. Bot. 44:509-518.

Horneck, D.A., J.M. Hart, K. Topper, and B. Koepsell. 1989. Methods of soil analysis used in the soil testing laboratory at Oregon State Univ. Oregon State Univ. Agr. Expt. Sta. SM 89:4.

Jones, R.A. 1986. The development of salt tolerant tomatoes: breeding strategies. Acta Hort. 190:101-114.

Kelly, S.F., J.L. Green, and J.S. Selker. 1997. Fertilizer diffusion in container medium. J. Amer. Soc. Hort. Sci. 122:122-128.

Kovalev, V.M. and N.P. Krylova. 1992. Use of halophytes to improve arid pastures. (Russian) Sel'skokhozyaistvennaya Biol. No. 4, 135141.

Maathius, F.J.M., T.J. Flowers, and A.R. Yeo. 1992. Sodium chloride compartmentation in leaf vacuoles of the halophyte Suaeda maritima (L.) Dum. and its relation to tonoplast permeability. J. Expt. Bot. 43:1219-1223.

SAS Institute. 1996. SAS/STAT user's guide, vers. 6.12, SAS Inst., Cary, N.C.

Sanchez, C.A. and J.C. Silvertooth. 1996. Managing saline and sodic soils for producing horticultural crops. HortTechnology 6:99-107.

Simon, F.W. 1978. The symptoms of calcium deficiency in plants. New Phytol. 80:1-15.

Van Goor, B.J. 1968. The role of calcium and cell permeability in the disease blossom-end rot of tomatoes. Physiol. Plant. 21:1110-1121.

Willumsen, J., K.K. Peterson, and K. Kaack. 1996. Yield and blossom-end rot of tomato as affected by salinity and cation activity ratios in the root zone. J. Hort. Sci. 71:81-98.

Winsor, G.W., P. Adams, and D. Massey. 1980. New light on nutrition. Suppl. Grower 93(8):99, 103.

Zhao, K.F. 1991. Desalination of saline soils by Suaeda salsa. Plant Soil 135:303-305. 